\title{
TEOLOGIA W SŁUŻBIE WIARY - REFLEKSJA NAD LEKTURA KATECHEZY BENEDYKTA XVI „RADOŚĆ WIARY”
}

Radość Wiary Benedykta XVI jest niewątpliwie ważną pozycją zarówno dla osób na co dzień zajmujących się teologią, jak i tych, którzy nie są z nią zawodowo związani, a którzy chcieliby pogłębić lub na nowo ożywić swoja wiarę. Wiara, mając charakter dynamiczny, ciągle wymaga nowych inspiracji i bodźców. Ponieważ tylko taka wiara może w swym dynamizmie wyjść poza indywiduum, które ją wyznaje i dotrzeć do ludzi, którym była dotychczasowo obca. Wydaje się, że jest to warunek bardzo ważny, a może nawet konieczny do realizowania wciąż na nowo misyjnego wezwania Chrystusa, do którego powołany jest każdy wierzący. Skarb wiary nie może być schowany pod korcem. Musi być przekazywany dalej. Musi nieść autentyczną radość, wynikającą ze spotkania z Bogiem, musi wprowadzać Jego światło do życia poszczególnych jednostek, grup społecznych czy narodów.

\section{WIARA JAKO PELNE NADZIEI SPOJRZENIE NA LUDZKĄ EGZYSTENCJE}

Pomimo wielkiego znaczenia dla życia człowieka, wiara, jeśli nie jest odpowiednio ożywiana, może ulec czasem pewnemu upowszednieniu. Może przestać być wartością na nowo odkrywaną, lecz stać 
się czymś na pozór oczywistym, deklarowanym, ale niebudzącym już zachwytu i pragnienia rozwoju.

Benedykt XVI wychodzi naprzeciw takiemu stanowisku i pomaga nam jeszcze raz spojrzeć ze świeżością na łaskę wiary. Wzbudzić entuzjazm, pobudzić nasz intelekt $i$ wolę do ponownego odkrywania Źródła i filarów naszej wiary. Napisana z okazji Roku Wiary katecheza mówi o rzeczach najważniejszych dla chrześcijanina w sposób dynamiczny, niezwykle interesujący i inspirujący. Daje bowiem wiele praktycznych wskazówek. Radość Wiary wychodzi naprzeciw materialistycznym i zsekularyzowanym wizjom społeczeństw i człowieka. Ukazuje złudność koncepcji zakładającej konieczność „uwolnienia” się człowieka od wiary, która ma być gwarantem jego wolności czy „dojrzałego" patrzenia na świat oraz miejsce człowieka w tym świecie. Papież występuje również przeciwko koncepcjom prowadzącym do osłabienia i wykorzenienia znajomości prawd wiary, które spotykamy nie tylko na zewnątrz chrześcijaństwa, ale i w jego obrębie, które przybierają postać zindywidualizowanej wiary odłączonej od Tradycji i Kościoła. Benedykt XVI ukazuje, że taka zindywidualizowana, prywatna wiara, która szuka swojego uzasadnienia i spełnienia jednie w osobistej wrażliwości i w ramach jednostkowego umysłu może prowadzić do stworzenia błędnego obrazu Boga. Fantastycznej wizji Chrystusa, który istnieje jedynie w wyobraźni.

W sekularyzowanych, nastawionych głównie na materialny wzrost, tak zwanych społeczeństwach wysoko rozwiniętych, wiara w Boga postrzegana jest jako sprawa indywidualna. Dla Papieża jest ona jednak punktem wyjścia, inspiracją do rozważań. Stanowi centrum prawdy, miłości i spotkania Boga z człowiekiem. Benedykt XVI ukazuje, że marginalizacja Boga, jest dramatem nowoczesnych społeczeństw. Takie działania dają jedynie pozory wolności, ponieważ w ten sposób odrzuca się Źródło wszelkiej wolności, którym jest Bóg․ Współcześnie promowana „wolność” od Boga musi z konieczności doprowadzić do zniewolenia człowieka, nie może dać mu szczęścia, za którym tak ustawicznie świadomie i nieświadomie

${ }^{1}$ Por. B e n e dykt XVI, Encyklika ,, Spe salvi”, nr. 30-31. 
tęskni. Powołany do Komunii z Bogiem człowiek nigdy nie znajdzie pełnego zaspokojenia w tym, co może dać świat. Współczesny kult życia tu i teraz bez perspektywy czegoś, co wykracza poza materię, musi skończyć się rozczarowaniem. To redukcjonistyczna wizja człowieka, która nie odpowiada na jego najgłębsze przyrodzone potrzeby.

W tym kontekście Papież zauważa, że „Kontynuować życie na wieczność - bez końca, jawi się bardziej jako wyrok niż dar. Oczywiście, chciałoby się odsunąć śmierć jak najdalej. Ale żyć zawsze, bez końca - to w sumie może być tylko nudne i ostatecznie nie do zniesienia. (...) Oczywiście, jest pewna sprzeczność w naszym postępowaniu, która wiąże się $\mathrm{z}$ wewnętrzną sprzecznością naszej egzystencji. Z jednej strony nie chcemy umierać; zwłaszcza ci, którzy nas kochają nie chcą naszej śmierci. Z drugiej jednak, nie pragniemy też istnieć w nieskończoność, a także ziemia nie została stworzona z taką perspektywą. Czego wiec tak naprawdę chcemy? Ta paradoksalność naszej własnej postawy rodzi głębsze pytanie: czym w rzeczywistości jest «życie»? Co w rzeczywistości oznacza «wieczność»? Są chwile, w których niespodziewanie zaczynamy rozumieć: tak, to jest właśnie to - prawdziwe «życie» - takie powinno być. Przeciwnie, to, co na co dzień nazywamy życiem w rzeczywistości nim nie jest. (...) W jakiś sposób pragniemy życia, tego prawdziwego, którego potem śmierć nie tknie; równoczesne nie znamy tego, ku czemu zmierzamy. Nie możemy zaprzestać dążenia do tego, a równocześnie wiemy, że to wszystko, czego możemy doświadczyć, albo co możemy zrealizować, nie jest tym, czego pragniemy. Ta nieznana «rzecz» jest prawdziwą «nadzieją», która nas inspiruje, a jej niepoznawalność jest równocześnie przyczyną wszelkiej rozpaczy, jak też wszelkich pozytywnych czy destruktywnych zrywów w stronę autentycznego świata i autentycznego człowieka"2.

Tylko dzięki Bogu życie człowieka nie musi być porażką. W Nim to człowiek otrzymuje właściwy sens i cel życia. Wyrazem tego są miedzy innymi pierwsze słowa Credo, które katolicy powtarzają podczas każdej Mszy Świętej. Podkreślają one często niewygodną dla

\footnotetext{
2 Tenże, Radość Wiary, Częstochowa 2012, s. 180-183.
} 
współczesności prawdę, że człowiek nie jest bytem przypadkowym, efektem ubocznym ewolucji, lecz świadomą intencją, rzeczywistością, która powstała z woli Boga. Konsekwencją odłączenia się od Boga musi być odłączenie się od źródła własnego życia. Papież pisze, że: „Kiedy w pierwszych chwilach nieobecności Boga Jego światło nadal promieniuje i podtrzymuje ład ludzkiej egzystencji, wydaje się, że również bez Boga wszystko funkcjonuje dość dobrze. Ale im bardziej świat oddala się od Boga, tym wyraźniej widać, że człowiek coraz bardziej traci życie w «hybris» władzy, w pustce serca $i$ tęsknocie do spetnienia i szczęścia. Nie da się wykorzenić istniejącego w człowieku pragnienia nieskończoności”’3.

\section{WIARA JAKO ZAUFANIE PRAWDZIE, KTÓRA JEST OBECNA W BOGU}

Wobec materialistycznego świata afirmującego sprowadzanie prawdy do poziomu opinii i wywyższającego osobowe opinie do wymiaru prawdy, który w imię postępu i poprawności zrównuje różne koncepcje Boga, chrześcijanie zobowiązani są do głoszenia Żywego Boga i Jego nieustannej obecności w życiu jednostek i wspólnot. Idea stworzenia występuje w wielu kulturach, jednak lektura Biblii ukazuje, że nie jakiś przypadkowy bóg, ale jedyny prawdziwy Bóg potęgą swojego stwórczego Słowa powołał do istnienia wszystko. Stworzenie, które powstało z Jego woli jest mu drogie. Jest przez Niego chciane. Błędem jest, jak pisze Benedykt XVI, zakładanie, że w rozwijającym się samoistnie wszechświecie, w jakimś jego odległym zakątku powstał w bliżej niewyjaśniony sposób gatunek zdolny do myślenia, który pragnie nadać stworzeniu sens. Bóg, który stworzył człowieka, stworzył go wolnym aktem woli. Kocha człowieka i chce jego szczęścia. Stworzył także świat wokół ludzi, dlatego też jak pisze Papież: „nie wolno nam używać świata i materii, tak jakby były to przedmioty zależne tylko od naszego działania i naszej woli’4.

\footnotetext{
3 Tamże, s. 18-19.

4 Tamże, s. 72.
} 
Boga Ojca nikt nigdy nie widział. A jednak obraz Boga nie jest abstrakcyjnym pojęciem teologicznym. Bóg posiada oblicze i ukazał je ludziom w osobie Jezusa Chrystusa. Święty Bóg, Pan wszechświata staje się człowiekiem i dzieli z nim wszystko oprócz grzechu. Bóg wkroczył w historię człowieka, nauczał, wyrzucał złe duchy, uzdrawiał chorych, by w końcu umrzeć na krzyżu, pokonać śmierć i zmartwychwstać. Chrystus, który umarł i zmartwychwstał jest centralną prawdą wiary, centralnym wydarzeniem historii. Chrystus ukazuje siebie, jako Pana życia, nad którym śmierć nie ma władzy. Który umarł, wstąpił do nieba i powrócił do ludzi, aby się z nimi spotkać. Bóg Ojciec obdarzył chwałą samego siebie w osobie Syna, którego ofiara przyciągnęła wszystkich do Niego i do Ojca.

Tajemnica paschalna pozwala nam obserwować zmianę wiary apostołów z naiwnej, jaką mieli jeszcze podczas ziemskiego nauczania Chrystusa, do wiary dojrzalej i pełnej. Jak Pisze Benedykt XVI: „Tajemnica zmartwychwstania Syna Bożego, który wstąpiwszy do nieba, by zająć miejsce obok Ojca, zesłał nam Ducha Świętego, pozwala nam jednym spojrzeniem ogarnąć Chrystusa i Kościół: Zmartwychwstałego i zmartwychwstałych, Pierwocinę i Boże pole, Kamień Węgielny i żywe kamienie, by posłużyć się innym obrazem zawartym w Pierwszym Liście św. Piotra (por. 2, 4-8). (...) Istotnie od dnia Pięćdziesiątnicy światto zmartwychwstałego Pana przemieniło życie apostołów. Mieli oni już wyraźną świadomość, że nie są zwykłymi adeptami nowej i interesującej doktryny, ale wybranymi i odpowiedzialnymi świadkami Objawiania, z którym wiązało się zbawienie ludzi im współczesnych i wszystkich przyszłych pokoleń”,

\section{WIARA JAKO OWOC DZIALANIA DUCHA ŚWIĘTEGO}

Chrystus nakazał apostołom głoszenie Jego nauki wszystkim narodom i posłał Kościołowi Swojego Ducha. Benedykt XVI przypomina, że wiara w Ducha Stworzyciela stanowi podstawową treść

5 Tamże, s. 62. 
chrześcijańskiego Credo. Materia jest ukształtowana w sposób racjonalny, matematyczny, dlatego ludzie są w stanie ją zrozumieć i przekształcać. Duch, który stworzył tę logiczną strukturę, stworzył także rozum człowieka, nadając mu wymóg rozumnego z niej korzystania. Właśnie dlatego, że natura ma charakter logiczny, człowiek może nią władać, ale i jest za nią odpowiedzialny. Jest ona darem Stworzyciela, który nie może być wykorzystywany bezmyślnie. Wewnętrzny porządek natury implikuje wskazówki, orientację etyczną, z jaką mamy odnosić się do odblasku Ducha Stworzyciela ${ }^{6}$. Wbrew temu, co głoszą materialistyczni filozofowie, Duch, który ukształtował matematyczny porządek świata natury jest czymś więcej niż ewolucją, matematyką. Jest On, jak wierzymy, osobowym dobrem, który ukazuje nam (również poprzez naturę stworzenia) drogę życia zgodną z Jego wolą. Papież podkreśla, że pominięcie, zlekceważenie charakteru języka stworzenia, doprowadziłoby do samozniszczenia człowieka, czyli zniszczenia dzieła Boga.

Benedykt XVI dotyka tutaj pojawiającego się dziś często w dyskursie publicznym pojęcia gender, angażując się tym samym w społeczną debatę dotyczącą tego zjawiska. Kościół jest bowiem zobowiązany reagować na pojawiające się trendy umysłowe, szczególnie jeśli dotyczą one prawdy o stworzeniu. Wedle filozofii gender człowiek nie jest w żaden sposób zależny od Stwórcy. Może tworzyć sam siebie wedle własnego upodobania i swobodnie dysponować wszystkim, co go dotyczy. Nie odmawiając człowiekowi prawa do wolności, Papież zauważa jednak, że w tym przypadku człowiek zaprzecza prawdzie. Występuje wiec przeciwko Duchowi Stworzycielowi. Kościół nie może być niemy, gdy chodzi o prawdę o stworzeniu, a w szczególności o prawdę dotyczącą człowieka stworzonego na obraz Boga.

Dokonując wielu spostrzeżeń dotyczących pneumatologii, Benedykt XVI podkreśla, że Duch Stworzyciel objawia się nie tylko W wielkości wszechświata, jego matematycznej rozumnej strukturze, którą właśnie dzięki temu usystematyzowaniu możemy poznawać. „Duch - jeśli można tak powiedzieć przemawia również ludzkimi

${ }^{6}$ Por. J. R a t z ing e r, W drodze do Jezusa Chrystusa, Kraków 2005, s. 34-35. 
słowami, wszedt $w$ historię $i$ jako siła kształtująca historię jest również duchem przemawiającym; co więcej, jest Słowem, które w pismach Starego i Nowego Testamentu przychodzi do nas. (...) Czytając Pismo, i my możemy także dzisiaj niejako przechadzając się po raju i spotykać przechadzającego się tam Boga. «Duch Święty» oraz «Słowo Boże» - występują razem. Czytając Pismo, dowiadujemy się jednak, ze także Chrystus i Duch Święty są nierozłączni. (...) Czytając Pismo razem z Chrystusem, uczymy się słuchać w ludzkich słowach głosu Ducha Świętego i odkrywamy jedność Biblii"’ Duch Święty jest Duchem Boga, który daje stworzeniu i historii Jego tchnienie, jest mostem komunikacji ludzkości z Chrystusem i Bogiem Ojcem.

Duch Święty kieruje misją Kościoła. Kościół, będąc Ciałem Chrystusa, jest również organizmem Ducha Świętego. Jego dary łączą wierzących w jedną całość. W tym mistycznym Ciele wierzący nie żyją w odosobnieniu, ale wzajemnie na siebie oddziałują, trwając w Chrystusie, który przyciąga nas poprzez swojego Ducha. Kościół ze swej istoty nastawiony jest na zbawienie wszystkich ludzi. Dlatego też nigdy nie jest zależny od podziałów państwowych, czy kulturowych. Jest rzeczywistością zobowiązaną do przekraczania stworzonych przez ludzi granic. Jego zasadą jest jedność i uniwersalność, ponieważ inicjuje jednoczenie różnych ludzi, niejednokrotnie posiadających odmienne stanowisko, na przykład w sprawach politycznych, ekonomicznych czy społecznych. Można powiedzieć, że właśnie jedność w różnorodności jest znakiem rozpoznawczym Kościoła.

Jedność Kościoła, która rozciąga się nie tylko na wierzących, która rozciąga się na wszystkie pokolenia i na wszystkie epoki i we wszystkich miejscach świata jest dziełem Ducha Świętego. Dlatego doświadczenie Chrystusa Zmartwychwstałego nie było jedynie doświadczeniem apostołów u zarania Kościoła, ale może być i jest przeżywane przez kolejne pokolenia. Jest ono wciąż przeżywane w jedności życia Kościoła i liturgii. Papież Benedykt XVI podkreśla,

7 B e n e d y k t XVI, Radość Wiary, dz. cyt., s. 79; Por. J. Ratzinger, Chrystus i Jego Kościót, Kraków 2005, s. 104-108. 
że indywidualistyczna interpretacja nauk głoszonych przez Chrystusa, bez uwzględnienia Tradycji i związanego z nią autorytetu nauczycielskiego Kościoła, narażana jest na wybiórczość i jednostronność, a więc i błędy ${ }^{8}$. Indywidualizm teologii liberalnej stoi w opozycji do misji Chrystusa, Jego posłannictwa, która ma charakter wspólnotowy. Nauczanie Chrystusa ukierunkowane jest bowiem na zjednoczenie rozproszonego Ludu Bożego. Na jego zgromadzenie wobec rozproszenia.

\section{WIARA JAKO DROGA PROWADZĄCA DO ZBAWIENIA}

Świadomość ponadkulturowej jedności była dla pierwszych chrześcijan oczywista. Rozumieli, że wiara w Chrystusa nie jest jedną z wielu form życia religijnego, ale należy do sfery prawdy, że w osobie Chrystusa, Bóg się rzeczywiście objawił i dlatego dotyka w równym stopniu wszystkich. Jak pisze Papież: „Pan daje zbawienie wszystkim ludziom w każdej epoce. Wszyscy dostrzegamy, jak ważne jest, by światło Chrystusa oświecało każde środowisko człowieka: rodzinę, szkolę, kulturę, prace, czas wolny i inne dziedziny życia społecznego. Trzeba głosić nie jakieś słowo pociechy, lecz słowo, które porusza, wzywa do nawrócenia, umożliwia spotkanie z Nim, dzięki któremu rozkwita nowa ludzkość"9. Kościół i wszyscy wierni wciąż na nowo jest wezwany do głoszenia słowa Bożego, które zbawia. Niedopuszczalne jest, by jego posługa ograniczała się tylko do tych, którzy znają nauczanie Chrystusa. Ponieważ Kościół ma obowiązek misyjny głoszenia prawdy wszystkim ludziom i narodom nawet w obliczu niezrozumienia, wiąże się to ze stawaniem w opozycji do

${ }^{8}$ Por. Tenże, Trzeciego dnia Zmartwychwstat, w: Przestanie Zmartwychwstania, Paweł VI, J. Ratzinger/Benedykt XVI, Cantalamessa, Pronzato i inni, Kraków 2007, s. 18-25.

9 B e ne dykt X V I, Radość Wiary, dz. cyt., s. 118. 
promowanych przez nowoczesne społeczeństwa wartości niezgodnych z duchem wiary, a nawet z prześladowaniami ${ }^{10}$.

Wcielenie Słowa Bożego jest rzeczywistym początkiem Kościoła. Jego teologicznym uosobieniem jest Maryja, jako pomost pomiędzy Chrystusem i wspólnotą wierzących. Jest ona wzorem duchowości, odwagi, pobożności, szukania i poddania się woli Boga, do której wezwany jest każdy z nas. Maryja pokazuje nam, że oddając się całkowicie Bogu, człowiek nie traci wolności, jak próbuje to insynuować powszechny dziś laicki światopogląd. Wręcz odwrotnie jej przykład uzmysławia, że tylko żyjąc w Bogu człowiek staje się naprawdę wyzwolony, uwznioślony, godny. Ponieważ tylko zapraszając Boga do swojego życia, człowiek może stać się w pełni sobą. Będąc blisko Boga, człowiek przestaje się skupiać wyłącznie na sobie. Egoizm ustępuje miejsca empatii i altruizmowi. Ponieważ wiara niesie z sobą wrażliwość i otwarcie na drugiego. Zamienia strach w odwagę, niechęć w poczcie mocy a duchową apatię w zapał. Matka Zbawiciela, jest Matką Kościoła a jej bezwarunkowe „tak” jest wzorem dla wszystkich wierzących.

Kościół uczestniczy w wielu formach kultu, spośród których najwyższą jest sakrament. Sakrament oznacza uprzedzający ludzkie działanie akt Boga, który wychodzi w ten sposób na spotkanie człowiekowi. Podczas sakramentu Bóg posługuje się materią - darami świata dostępnymi człowiekowi. Sakramenty prowadzą wiec do życia w Bogu, stanowią żywe serce Kościoła. Są obrazem życia i wiary chrześcijan, której celem jest życie wieczne pozbawione złudnych wyobrażeń doczesności. Nieopisana radość, do której z miłości zaprasza nas Bóg.

$* * *$

Współczesność wydaje się coraz częściej zapominać o Bogu. Nie jest On już postrzegany jako punkt odniesienia, gwarant praworządności, wyznacznik relacji międzyludzkich czy kierunku rozwoju

10 Por. J. R a z i nge r, Wyktady bawarskie z lat 1963-2004, Warszawa 2009, s. $57-58$. 
społeczeństw. Świat zewnętrzny jest często krzykliwy, nachalny, perswazyjny, podporządkowany koniunkturze. Bóg jawi się w nim, jako wartość, ale już nie jako wartość absolutna, lecz prywatna. Wartość nie obiektywna, ale jednostkowa, osobista, intymna, wypierana ze sfery publicznej. Zepchnięte na margines życia społecznego chrześcijaństwo traktowane jest jako jedna z wielu propozycji, ujście dla duchowych i etycznych potrzeb człowieka, wentyl bezpieczeństwa, czy rodzaj personalnego azylu, który nie ma prawa pretendować do roli prawdy objawionej, a jeżeli już, to na równi z innymi „prawdami objawionymi” jakie wyznaje ludzkość. Świat mediów, konwenansów i pewnego rodzaju poprawności kulturowej nie może pogodzić się z religią, która nie zważając na obowiązujące modne opnie stoi na straży prawdy, która choć zawsze ważna jest czasem trudna i wymagająca.

Wiara, o której pisze Benedykt XVI, nie jest jedynie dodatkiem do życia. Jej celem nie jest wyłącznie wypełnienie metafizycznej pustki, powodowanie i podtrzymywanie duchowej strefy komfortu człowieka. Nie jest fantazją ani urojeniem, ale żywą odpowiedzią na wezwanie Chrystusa. Nawet za cenę społecznego ostracyzmu, niezrozumienia, wykluczenia, narażenie się światu. Wiara łączy się z ryzykiem, ale też z odwagą bycia odpowiedzialnym. Jest wezwaniem do udzielenia odpowiedzi, ustosunkowania się do zewnętrznej i wewnętrznej rzeczywistości w sposób świadomy i wolny. Entuzjastyczna odpowiedź na wezwanie Chrystusa, nie gwarantuje tego, co jako swój priorytet traktuje współczesna kultura, czyli przyjemności opartej na konsumowaniu życia. Daje jednak radość, której nie może dać świat.

\section{Summary}

THEOLOGY IN THE SERVICE OF THE FAITH REFLECTIONS ON "THE JOY OF THE FAITH" BY BENEDICT XVI

In a contemporary, secularized society, faith is undervalued and marginalized. How can we find the "joy of faith" nowadays? A deepening response to this question is found in "Joy of Faith," which is a type of catechesis by Pope Benedict 
XVI connected to the Year of faith. A re-reading of Pope's thought gives a special opportunity to realize the apparent truth that modern theology serves to awaken the "joy of faith." Turning this thought aside: believers need contemporary theology so that their faith can be deepened, joyful and courageous in the discourse with "apostles" of religious indifference and moral relativism. Reading of papal catechesis reveals that faith gives a renewed glimpse into human existence, enables us to discover in God the source of truth, introduces in the experience of the action of the Holy Spirit and of the Church, and finally gives assurance of salvation, which for the Christian is the foundation of the ultimate (eschatological) joy.

Słowa kluczowe: Wiara, radość wiary, Rok wiary, teologia, Benedykt XVI, J. Ratzinger

Key words: Faith, the joy of the faith, the Year of Faith, theology, Benedict XVI, J. Ratzinger

\section{Bibliografia}

B e n e d y k t XVI, Encyklika „Spe salvi”.

B e ne dykt XVI, Radość Wiary, Częstochowa 2012.

R a t zinge r J., Chrystus i Jego Kościót, Kraków 2005.

Ratzinge r J., Trzeciego dnia Zmartwychwstat, w: Przesłanie Zmartwych-

wstania, Paweł VI, J. Ratzinger/Benedykt XVI, Cantalamessa, Pronzato i inni, Kraków 2007, s. 18-25.

R a t z ing e r J., W drodze do Jezusa Chrystusa, Kraków 2005.

R at zinger J., Wykłady bawarskie z lat 1963-2004, Warszawa 2009. 